\title{
Mekânın poetikası olarak Safiye Erol'un romanlarında İstanbul ve Edirne
}

\section{Necla DAĞ́1}

APA: Dă̆, N. (2019). Mekânın poetikası olarak Safiye Erol'un romanlarında İstanbul ve Edirne. RumeliDE Dil ve Edebiyat Araştırmaları Dergisi, (Ö6), 96-10. DOI: 10.29000/rumelide.648431

\section{$\ddot{O} \mathbf{z}$}

Roman, öykü, makale ve incelemeleri ile tanınan Cumhuriyet dönemi yazarlarından Safiye Erol, küçük yaşlardan itibaren almaya başladı̆̆ı dil eğitimini tamamlamak üzere Almanya’ya gider. Almanya'da doktora eğitimini tamamlayarak ülkesine dönen Erol, Batı ve Doğu kültürlerine ait ögeleri çalışmalarında başarılı bir şekilde işler. Avrupa'da gezip gördüğü yerler ile ülkesi arasında kıyaslamalar yaparak eğitim, edebiyat, sanat, kadın yaşamı, müzik ve eğlence anlayışı gibi çeşitli konulara ilişkin değerlendirmelerde bulunur. Safiye Erol'un aşka bakışı onun şehrin farklı semtleri üzerine yoğunlaşmasını sağlar. Tabiat unsurlarının yanı sıra tarihsel gelişimi de dikkate alan yazar, şehri kişiselleştirerek ona bir canlı gibi seslenir. Olayların kurgulanmasında şehrin dokusunu merkezî bir yere oturtan Safiye Erol, romanlarında İstanbul ve Edirne için özel bir yer ayırır. Bu iki şehrin Osmanlı'nın kuruluş ve diğer dönemlerindeki önemine binaen tarihsel dokularına bir kutsallık atfeder. İstanbul ve Edirne; tarihî, kültürel, ekonomik ve sosyal yapılarıyla kahramanların yaşadığı olaylara tanıklık eder. Kahramanların gelişimini tamamlamaları ve seçimlerde bulunmaları; şehrin kişi üzerinde bıraktı̆̆ı etkiyle özdeşleştirilir. Ayrıca yazar, Edirne ile olan bağlarını ve atalarının yaşamını ele aldığı hikâyeler aracılığıyla okuyucularına sunar. Bu çalışmada geçmiş, an ve gelecek betimlemeleri altında Safiye Erol'un romanlarında ele alınan şehirlerin bir poetika olarak okunuşu üzerinde durulacaktır. Yazarın şehirlere bakış açısı kültürel ve tarihî bağlar üzerinden değerlendirilecektir. Safiye Erol'un mekân poetikası, kahramanların yaşayışları üzerinden incelenecektir.

Anahtar kelimeler: Mekân, Safiye Erol, şehir, kültür.

\section{Istanbul and Edirne in Safiye Erol's novels as poetika of space}

\begin{abstract}
Safiye Erol, one of the writers of the Republican period known for his novels, stories, articles and reviews, goes to Germany to complete his language education, which he started to receive from an early age. Returning to his country after completing his PhD in Germany, Erol successfully studies the elements of Western and Eastern cultures. She makes comparisons between the places she has traveled and seen in Europe and her country, making assessments on various subjects such as education, literature, art, women's life, music and entertainment understanding. Safiye Erol's conception of Love has a Sufi tendency from time to time, which allows him to focus on the city. The author examines the history of the city as well as the elements of nature, personalizing the city and calling it a living thing. Safiye Erol, who places the city in a central place in the fictionalization of events, sets aside a special place for Istanbul and Edirne in her novels. He attributes a sanctity to the historical textures of the city, building on the importance of these two cities in the founding and other
\end{abstract}

1 Öğr. Gör. Dr., Aksaray Üniversitesi, Türkçe Öğretimi Uygulama ve Araştırma Merkezi (Aksaray, Türkiye), necladago2@gmail.com, ORCID ID: 00oo-0002-7961-2960 [Makale kaytt tarihi: 06.10.2019-kabul tarihi: 20.11.2019; DOI: $10.29000 /$ rumelide.648431] 
periods of the Ottoman Empire. Istanbul and Edirne; it bears witness to the events experienced by the heroes with its historical, cultural, economic and social structures. The fact that the heroes complete their development and make choices is identified with the impact the city has on the person. This study will focus on the recitation of the cities covered in Safiye Erol's novels as poetics under the descriptions of the past, the present and the future. The author's perspective on cities will be evaluated through cultural and historical links. The importance of Safiye Erol's space poetics and novelism will be emphasized.

Keywords: Place, Safiye Erol, city, culture.

\section{Giriş}

Poetika kavramı için pek çok farklı tanım yapılmaktadır. İlk olarak Aristoteles (2001: 9), "Poetika" adlı eserinde terimi, mimesis (taklit) ile ilişkilendirerek dram, epik ve trajedinin özellikleri ilişkili olacak şekilde açılar. İsmail Tunalı ise "estetik" kelimesiyle terimi anlamlandırmaya çalışır. Sözcük, Yunancada "yapmak, yaratmak, düzenlemek" anlamına gelen "poiein" fiilinden türemiştir. Bu kökten türeyen "poiema" "yapılmış şey, eser", "poietes" de "sanatçı" (Özgül, 2001: 223) anlamında kullanılır. Todorov'a göre (2014: 108); poetika, "belli bir edebi yapıtın işlemesini sağlayan şey(ler)dir". Okay (1998: 34), poetikayı "şiirin güzeli yakalayabilme gücü, şiirin kaynağı, okuyucu ve tenkitçi huzurunda şiir” basit bir karşılıkla "şiir sanatı" olarak tanımlar. Aytaç (2003: 362); şiir öğretisi, doğru ve güzel yazmanın normatif rehberliği, edebiyat eleştirisi karşlıklarıyla poetikayı tanımlar. Sazyek'e göre (2000: 10), poetika, "bizzat şairlerin (kendi) şiir(lerin)in biçimini, içeriğini, üslubunu ve estetiğini kapsayan konularda herhangi bir sanatçııı ya da eseri hedef almaksızın ortaya koyduğu görüşleri, tespitleri, önerileri, içeren çalışmalar(ın)dan meydana gelen bir bütün”dür. Bu tanımlardan kavramın genellikle şiir ile bağdaştırılarak açılandığı görülmektedir. Ancak Todorov (2014: 38), bu duruma karşı çıkar ve poetikanın yalnızca manzum türlerle değil; edebiyatın her türü ile ilişkili olduğunu savunur. Todorov'un bu görüşünden hareketle sanatçı, poetikasını romanlarında, mektuplarında, makalelerinde veya herhangi bir söyleşisinde ifade edebilir denilebilir. Çetin'e göre (2017:75), poetika; tek tek eserler üzerinde durmaktan ziyade, onları bir hareket noktası olarak alıp oradan eserin oluşumundaki temel ilkeleri tespit eden sistemli bir anlamlandırma/açılama çabasıdır”. Poetikanın birçok alanı kapsayan geniş bir kavram olması nedeniyle edebî metne ait mekân incelemelerinde de kavramın ele alınması gerekmektedir. Safiye Erol'un poetikasını romanları, makaleleri ve çeşitli söyleşileri üzerinden okumak ve anlamlandırmak mümkündür. Böylece belli bir mekânda yaşananlar bireysel ifade biçimini şekillendirerek poetik bir tavra dönüşecektir.

Bachelard, Mekânın Poetikası (1996) adlı çalışmasıyla mekânın, hafıza ve düş kavramlarıyla birlikte ele alınması gerektiğini belirtir. Böylece mekân üzerinden değerlendirilen düş ve hafıza, anıları canlı tutacaktır. Hayalin çağrıştırdığı anlam, mekânda yaşanmışlık ile ortaya çıkar. Bachelard'a göre (1996); düşler, yaşanmışlıklar, anılar, bir yerin anlam kazanmasında ve öznellik kazanmasında büyük rol oynar. Edebî metinlerde mekânın geçmişten günümüze kadar uzanan bir önemi vardır. Mekân olarak bir şehir ele alınıyorsa şehrin yapısıyla insan ruhunun etkileşimi kültürel uyumu tamamlarlar. Şehirlerin gelişimi ile insan yaşamı da paralel gelişerek farklı bir nitelik kazanabilmektedir. Bu gelişim olumsuz yönde bir çizgide devam ederse toplumsal ve kültürel bazı çözülmeler ortaya çıkar. Bu nedenle edebî metinlerde mekânın işlevsellik kazanmasında şehirler büyük bir önem kazanmaktadır. Bazen şehrin tarihsel bir mekân oluşuyla; bazen de medeniyet kavramının şehre kattıklarıyla ilgili değişiklikler bireyin hayatına yön vereceği gibi toplumların hayatını da etkileyebilmektedir. Bu anlamda "mekânlar, insanın iç dünyasını ve yetiştiği kültürü bire bir yansıtan önemli bir 'yaşam' alanı, toplumların yaşadı̆̆ı değişimleri 
resmeden medeniyet aktarıcısıdır" (Balık, 2016: 121). Safiye Erol'un romanlarında ise mekân bir poetika olarak okunabilir. Kahramanların var oluşu, ön plana çıkışı veya silikleşmesi mekân üzerinden değerlendirilmektedir. Yaşanan ilişkiler ve olay örgüsünün akışı, gidilen veya terk edilen mekânın özelliğine bağlı olarak değişiklik göstermektedir. Her mekân içinde bulunulan anın atmosferini aktarır.

Kadıköyü’nün Romanı (1938), Ülker Fırtınası (1944), Ciğerdelen (1946), Dineyri Papazı (1955) romanlarında mekân başlı başına bir edebi unsur olarak ele alınmaktadır. Safiye Erol, bu romanlarında Edirne ve İstanbul şehirlerinin tarihsel özelliklerinden yola çıkarak dönemlere göre değişmenin toplum ve birey hayatındaki etkilerine işaret eder. Ancak şehirlerin belli semtlerini, yoğunlukları veya ıssızlıklarına göre bireyin ruh hâliyle bağdaştırarak öne çıkarır. Erol'un romanlarından şehirlerden sonra dikkat çekici unsur olay örgüsüdür. İyi bir eğitim almış; ancak aşk söz konusu olunca hastalıklı denecek kadar zayıf bir ruh haline sahip kadınların etrafında dönen olaylar, romanların alt yapısını oluşturur. Erol'un en çok dikkat çeken kahramanları, aşk için her şeyi göze alan, aşklarına karşllık bulmak için farklı yerlere savrulmaktan usanmayan kadınlardır. Birçok özellikleri ile yazarı temsil eden eğitimli kadınların aşk karşısında düştükleri zaaf, kahramanların kendi iç dünyalarına yönelişlerini hızlandırır. Bu durumda İstanbul'un semtleri veya Edirne; kahramanların iç dünyalarına yönelişlerine ya şahitlik eder ya da bu duruma yön verir. Safiye Erol, millı̂ değerler ile Almanya'da aldığı eğitim neticesinde edindiği değerleri harmanlayarak eserlerini oluşturduğundan, felsefe alanında yapmış olduğu doktoranın bilgi birikimini roman kahramanlarına başarı ile aktararak zaman zaman varlıkyokluk, var oluş amacı gibi konuları aşk, din ve psikolojik açısından mekânsal imgeler yoluyla ele alır.

\section{1. İstanbul'un aynası: Kadıköyü’nün Romanı}

Safiye Erol, 1942'de Kadıköy'de bir ev alarak yazlarını "Şifa Sokağı, İkbal Apartmanı’nda” (Savcan, 2005: 8) geçirir. Bu semtte yaşayarak Kadıköy'deki canlılığa yakından şahit olduğundan semtin ruhunu Kadıköyü'nün Romanı'na gerçek anlamda yansıtmıştır. Osmanlı İmparatorluğu'nun yıkılışından sonra aileler ve bireyler kadar değerler de değişim göstermiştir. Romanın kahramanları Cumhuriyet'in ilk kuşağı olan gençlerdir. İstanbul'un 1930'lu yıllarda geçirdiği değişim, Kadıköy semtinden hareketle yansitılır. "O zamanki Kadıköyü'nün bir tutanağı niteliğindeki roman, yörenin semtlerini, mevsimlere ilişkin özelliklerini, ünlü yapılarını, alaturka müzik fasıllarını, sandal gezintilerini, balık avcılığını büyük bir sevgiyle yansıtır" (İleri, 2015: 277-278). Kadıköyü’nün Romanı; Bedriye, Necdet ve Burhan adlı şahısların etrafına toplanan arkadaş grubunun yaşadığı olayları ele alır. Bireyler, yeni ülkenin kendilerine sunduğu imkânları sonuna kadar kullanarak eğlencelerde, müzik ve dans partilerinde bütün kaygılardan uzak bir hayat sürdürürler. Kadıköy dışında Moda, Haydarpaşa, Fenerbahçe, Şifa gibi semtlerde sürdürülen yaşam tarzı, Tanzimat dönemi alafranga züppe tipinin yaşamını çağrıştırır. Tanzimat'ın Batı hayranı bilgisiz, saf ve acemi kahramanlarının yerine Batı değerlerini tanıyan ve bu değerlere hayran olan bir kesim, İstanbul'daki modern yaşamı organize ederek şehri bir Batı şehrine dönüştürme çabası güderler. Romanın ana kahramanlarından Bedriye, güzelliŭi, bilgisi ve eskiyle yeniyi birleştiren görgüsüyle bütün mekânların gözdesidir. İstanbul'un çeşitli semtlerinde düzenlenen partilerde gözler daima Bedriye'yi arar. Genç gazeteci Necdet, Orhan, Burhan ve daha birçok kişi Bedriye'ye tutkundur. Nesrin çocukluk arkadaşı Necdet'e âşık olsa da Necdet'in Bedriye'ye olan ilgisini anlayarak Mükerrem ile nişanlanır. Bir süre sonra ise trafik kazası geçirerek ölür. Ancak kazanın şekli intihar etmiş olma ihtimalini güçlendirir. Kocasının ölümünden sonra uzun süre hayatına kimseyi almadan görümcesi Mihriban Hanımla birlikte yaşayan Bedriye, Fenerbahçe Plajınnda gördüğü Burhan'a âşı olur, bir süre sonra da aşkını itiraf ederek Burhan ile evlenir. Necdet için büyük bir yıkım olan bu evlilik, onun topluluktan uzaklaşmasının yanı sıra semt değiştirmesine de neden olur. Bedriye’nin evliliği, Burhan'ın ilgisizliği nedeniyle uzun sürmez. Roman kahramanlarından hiçbirinin 
aşktan yana yüzü gülmez. Her hafta bir mesire alanında veya davette bir araya gelen yedi kişilik grup, zamanla dağılarak İstanbul'daki bu eğlencelere son verirler.

Romanda yeni ile eski mekânlar varlığını bir arada sürdürmektedir. Cumhuriyet'in ilk döneminde görülen eski konaklar, köşkler, yalılardaki yaşam tam anlamıyla son bulmamıştır. Örneğin Bedriye, eşi yıllar önce vefat etmiş olsa da Cevizlik’teki köşkünde yaşamaya devam eder. Köşk anne gibi gördüğü görümcesinin varlı̆̆ıyla geçmişin bir simgesi olarak Türk kültürünün köklülüğünü gösterir. Ayrıca Bedriye, diğerlerinden yaşça büyük olması sebebiyle geçmiş ve gelecek arasında bir değer temsilcisi rolünü üstlenir. Onun yaşadığı köşk de inziva veya kaçış yeri olarak anlam kazanır. Köşkteki eşyalar ihtişamlı bir kültür ve medeniyetin izlerini taşır. Yazar, Bedriye'nin yaşadığı yerin özelliklerinden faydalanarak Batı ve Doğu medeniyetinin sentezini yaratmaya, bir yandan Osmanlı kültür varlıklarına bir yandan da modern yaşamın sunduğu İstanbul'daki gezinti, davet, eğlence mekânlarına yer verir.

Roland Barthes (1999: 268), "şehir bir söylemdir ve söylem de başlı başına bir dildir. Şehir, içinde yaşayanlarla konuşur" sözleriyle şehrin bir mekândan çok bir edebî metin olarak ele alınması gerektiğinden bahseder. Şehir, geçmişte yaşanılanlar kadar yaşanması umulanlara da ev sahipliği yapar. Bu bakımdan Barthes ’in söyleminde dile getirdiği şehrin içinde yaşayanlarla konuşması kadar bireyin şehirle konuşması, dertleşmesi, hayallerini kurarken şehrin imkânlarından yararlanması doğal bir süreç şeklinde işler. Safiye Erol'un kahramanları da kişiliklerine, yaşam biçimlerine ve hayallerinin gereklerine göre çeşitli semtlerde ve evlerde otururlar. Yazar, Nesrin ve teyzesi Nimet'in yaşamları üzerinden Feneryolu'na yoğunlaşırken sosyalleşen bir topluluğun faaliyetlerine, Mükerrem'in Acıbadem'deki köşküne ve Baha'nın Moda'daki dükkânına değinirken ekonomik durumun gelişmişliğine göndermede bulunur. Papazın Bağı ve Şifa, yazın eğlence yeri olarak tercih edilirken Mardik'in Meyhanesi kış eğlencelerine hizmet eder. Kahramanlar ayrıca Mulen Ruj, Moda Deniz Kulübü’nde de sık sık bir araya gelirler. Roman, gençler arasında düzenlenen eğlenceler üzerine kurulu olduğundan kaygısız, çalışma veya maddi kazanç elde etme gibi dertleri olmayan bu gençliğe eleştiri yine yazarın kendisinden gelir. Yazara göre “...Moda'da Kalamış’ta güneşlenip denize giren” bu kitle, "bir yandan gıda bir yandan tabiatla beslenerek" azmaktadır. Hepsi "kendilerine dert kılığında uydurma birer acı icat ederek" İstanbul'un sunduğu "dekor içinde gizli gizli gönül” (Erol, 2015a: 106) derdi çekmekten hoşlanmaktadır. İstanbul'un semtleri hissedilen duyguya göre yüceltilir ya da gözden düşürülür. Önceleri Necdet, Bedriye ve diğerlerini bir araya getiren Kadıköy, yaşanan ayrılıklardan sonra kahramanların kaçıp kurtulmak istedikleri bir mekâna dönüşür. Necdet, Kadıköy'den Cağaloğlu'na taşınırken Bedriye ise âşık olduğunda çektiği acıyı unutmak için kaçış mekânı olarak Bebek'e; boşandıktan sonra ise Viyana'ya sığınır. Böylece İstanbul, olayların merkezi olmaktan çıkarak anılarda kalan bir şehre dönüşür. İstanbul büyük aşkların yaşandığı bir şehirken aşktan vazgeçişlerle beraber özlem duyulan ancak uzak durulan bir şehir olarak anılarda kalır.

\section{Doğu-Batı çıkmazının romanı: Ülker Fırtınası}

Safiye Erol'un romanları Cumhuriyet dönemindeki atmosferi; ekonomik, sosyal, bireysel koşulları yansıtması bakımından önem arz eder. Doğu- Batı, genç-yaşlı kuşak, zengin-fakir çatışmasının yanı sıra önceki dönemde başlayan yanlış batılılaşma ve değerlerin kaybolması kahramanların karakteristik özelliği olarak öne çıkmaya başlar. Önceleri Yakup Kadri, Refik Halit Karay gibi yazarların eserlerine yansımış olan bu durum Safiye Erol'un da dikkatinden kaçmamıştır. Dolayısıyla bahsi geçen ikilemlerin odağında yaşamlara değinilerek bireylerin geçirdiği değişimler ele alınmıştır. 1. Dünya Savaşı'ndan sonra ortaya çıkan sorunlar, genç kuşağın Batıya olan hayranlığını artırırken önceki kuşağın geçmişe sığınmalarına neden olur. Bu durum tarihsel gelişmelerin geçmişin ışığından okunmasına, önceki 
dönemin mimari, sanatsal ve ekonomik koşullarını yücelten mekân tasvirlerinin yoğunlaşmasına neden olur. Erol'un Kadıköyü’nün Romanı'ından sonra yazdığı Ülker Fırtınası'nda tamamen zıt dünya görüşüne sahip bireylerin aşkları Doğu-Batı çatışmasıyla iç içe yoğun bir şekilde işlenir. Ülker Fırtınası'nda Kadıköyü’nün Romanı'na göre olaylar, daha iyi bir teknikle ele alınır. "Zira Kadıköyü’nün Romanı'nın kahramanları, takip ettikleri Batı kültür ve medeniyetini uzaktan öğrenip anlamaya çalışan kişiler iken; Ülker Fırtınası'nın genç nesli eğitimlerini Avrupa'da sürdürmekte olan bilgili ve donanımlı kimselerdir" (Erol, 2011: 399). Nuran, Selçuk ve Turan adlı gençler Batı'da aldıkları eğitimle yaşamlarına yön verirlerken olaylara karşı kararlı bir duruş sergilerler. Bu gençler, hayatlarını toplumun isteklerine ve kurallarına göre değil, kendi kararlarına göre düzenlerler.

Batı müziği eğitimi almış, Avrupa terbiyesi ile büyümüş bir genç kız olan Nuran, Sermet Rıfat’ı Doğu müziğinin icra edildiği bir toplantıda tanıyarak ona âşık olur. On dört yıllık evli, dört çocuk babası olan Sermet, alaturka müzik ile ilgilenip meyhanelerde ud çalarak hayatını kazanmaktadır. Dügün hazırlıkları tamamlanmak üzereyken Sermet'in evli olduğu ortaya çıkar. Bu durum Nuran'ın ağır bir psikolojik sarsıntı geçirip evine kapanmasına neden olur. Ancak bu durum, kahramanın Sermet'ten tamamen bir vazgeçtiğini göstermez. Nuran'ın ayrılıkları, tekrar dönüşleri onda gitgide hastalıklı bir ruh hali yaratır. İstanbul'un çeşitli semtleri, Nuran'ın ruh halinin gerektirdiği durumlara göre bir araya gelişler ve ayrılıklar sürecinde mesken olarak kullanılır.

Romanda kapalı mekânlar çok kullanılsa da esas mekân, İstanbul'dur. Şahıslar, yaşadıkları sorunların üstesinden gelemedikçe toplumdan kaçmak ve kendi kendilerine kalarak karar alabilmek için kapalı mekânlara sığınırlar. "Roman içindeki ilk kapalı mekân Nuran’ın Sermet'le tanıştığı Kanlıca'daki yalıdır. Yine Nuran, hayatındaki en büyük yanlışı bu yalıda yapar, çünkü Sermet'le gayrimeşru bir ilişkiye bu yalıda başlar" (Savcan, 2005: 124). Nuran'ın ilişkisine sahne olan bir diğer mekan Feneryolu'ndaki köşküdür. Sermet’in kendisini kandırdığını öğrendiğinde ve daha sonra Sermet'le ilişkisini sürdürdüğü dönemde bu köşk onun sakinleştiği tek yerdir. Toplumdan ilişkisini gizlemek için bu köşkü kullanır.

Bu dönemde İstanbul eğlenceleriyle ünlü olduğundan gazinolar göze çarpar. Sermet’in para kazanmak için ud çaldığı gazinoyu betimlemek ve onun kötü atmosferin içindeki sefilliğini öne çıkarmak amacıyla Beyoğlu'ndaki gazino, sanata ve sanatçıya değer verilmeyen, kirli, sefalet kokan bir yer olarak anlatılır. İstanbul'un başka bir yönü yoksul semtleridir. İstanbul köşklerin, konakların, yalıların olduğu semtlerin dışında fakirliğin kol gezdiği semtleriyle de işlenmektedir. Nuran ve yaşadığı semt anlatılırken Batılı bir kadın ve modern bir kent tasviri yapılır ancak bu semtlerde Sermet alıştı̆̆ı düzenin uzağında bir hayat sürmek zorunda kaldığından rahat değildir. Sermet’in sık sık aldattığı karısı ve çocuklarının yaşadığı Mühürdar'daki ev, Nuran'ın evinin aksine acıma duygusunu uyandıracak kadar kötü haldedir. Burası, yoksul, değer görmemiş, bakımsız insanların yaşamlarını sürdürdüğü İstanbul'un bir köşesidir. Sermet, bu evde mutlu olmasa da alıştığı sefalet yaşamının içinde Müzeyyen’in ona sağladığı özgürlüğe düşkündür. Müzeyyen’i ve çocuklarını bırakarak sık sık gönül ilişkileri yaşamak için evden ayrılan Sermet, Nuran'a duyduğu aşka rağmen bu evi tamamen bırakamaz. Müzeyyen ise bu evde çocukların karnını doyuracak bir şeyler bulmamanın telaşı içinde günlerini geçirir.

Müzeyyen mutfağa indi. Hay gözü kör olası sütçü!Borçlar ödenmediği için dünden beri sütü kesti. Çocuklara bu sabah ne vermeli? Evde çay da yok ki, pişirsin. (...) Yemek? Evet,yemek, geceuykularını kaçıran düşünce (Erol, 2015a:69).

İstanbul'un diğer bir özelliğini ortaya koyan mekan ise Nuran'ın babasının Maltepe'deki evidir. Burası diğer semtlerden ve mekanlardan farklı tasavvufi bir hava sunar. Ali Fethi Bey, Nuran'ın annesini kaybettikten sonra bir Bektaşi dervişi olarak hayatına devam etmiştir. Evi de Bektaşilik’in gerektirdiği 
şekilde sade ve temizdir. Örneğin evde gereksiz hiçbir eşyaya yer yoktur. İnsanın temel ihtiyaçlarını karşlayacak kadar eşya bulunur. Kendi ruhunu arındırmaya çalışan Ali Fethi Bey, evini de birkaç mütevazı eşyalardan kurmuştur. Nuran'ın kendisini rahat hissettiği tek yer burasıdır. Daralıp sorularına cevap bulamadıkça babasının evine sığınan Nuran, burada tasavvufi bazı telkinlerle huzur bulduğunu fark eder.

Küçük bir sofaüzerinde solda mutfak, sağda bir oda vardı: Orada soba yanıyordu. (...) Bu evde her şey ona düz bir çizgi kadar kolay, su kadar berrak göründü (Erol, 2015a: 131-132).

\section{Avrupa'dan Edirne’ye bir uygarlık romanı: Ciğerdelen}

"Şehirler, işaret ettikleri mimari özellikleri, tabiata tasarrufları, sanatsal ve estetik yönleriyle; ait olduğu toplumun sosyal yaşamlarını, kültürel ve manevi değerlerini temsil eden birer göstergeler dizgesidir" (Dumantepe, 2015: 431). Erol'un romanlarında bu göstergeleri en iyi şekilde sunacak olan iki şehir İstanbul ve Edirne'dir. Safiye Erol (2002: 136), "Her sene bahar aylarında Edirne'yi ziyaret etmeden duramam. Kâbe niyetine Selimiye'yi dolanırım...” diyerek Edirne'yi kutsar. Edirne, büyük bir devlete başkentlik yapmış olmanın gururunu Balkan Savaşı'nda aldı ̆̆ı yaraya rağmen taşımaktadır. Erol'un gözünde Edirne “Bursa'nın oğlu, İstanbul'un babası sayılır”. Çünkü Edirne Türk toprağı olma özelliğini kaybetmemek için yüzlerce şehit vermiş, Türk toprağı olma sıfatını kaybetmemiş bir şehir olduğundan yazarın gönlünde olduğu kadar kahramanlarının gönlünde de ayrı bir öneme sahiptir.

Ciğerdelen'de ayrı hikâyeler anlatılsa da olayların asıl yaşandığı en önemli mekân Keşan'dır. Romanın başkahramanı ve anlatıcısı olan Turhan Tuna, Keşan’ı bayındır hale getirmek ve ülkesine gönül borcunu ödemek için Avrupa'da eğitimini aldığı mimarlık projelerini memleketinde hayata geçirmek ister. Geriye dönüş tekniği kullanılarak Keşan’ın ve Edirne'nin mekânsal değeri üzerine değerlendirmeler yapılır. Edirne ve Keşan tarihsel bir yolculuk ile kutsal bir önem kazanır. Keşan'da sergilenen kahramanlık kadar hikâyeler ve efsanevi anlatımlarla da mekânın değeri artırılır.

... Tarih boyunca kâh şarkın kâh garbın davasını benimseyen Trakların yurdudur. Silâhları, atları, zevkle işlenmiş gümüş kupaları ve hepsinden ziyâde Omiros, Orfoys, Tamiris gibi esâtire göçen saz şâirleriyle ün almış olan o harikalı kavmin toprağında bir kasaba... (Erol, 2015: 11)

Edirne'nin siyasi ve kültürel geçmişinin zenginliğine değinen yazar, "Keşanlıların ellerinde hâlâ türlü türlü paraların gezdiğini, Küçük İskender zamanından bile kalan altınların, bazı eski yazılı madenlerin pullar, dukalar, gümüşlerin” (2015: 12) bulunduğunu ifade eder. Keşan’ın geçmiş dönemlere ait görüntüsü çeşitli hikâyelerle aktarılıp Edirne'nin zenginliği ve ihtişamı öne çıkarılır. Turhan Tuna, aynı zamanda projelerini uygulamak için dolaşırken gününün Edirne'sinden görüntüler aktarır.

Çarşı içinden İzzet Molla'nın sürgün kaldığı Hacıborazan Han’ı üzerinden eski gâvur mahallesine kadar çıkıyorum. Orada burada eski binalardan bazıları kalmış, Keşan'ın yerli yeşil granitinden yapılmış hepsi bir stilde düz ve kibar yüzlü evler, mağazalar, ambarlar... (Erol, 2015b: 14)

Edirne sadece fizikî mekân olarak değil sosyolojik yapısı ile de romana yansır. Toplumun yaşayışı, konuşması, giyimi Edirne'nin gelenek ve göreneklerine göre işlenir. Edirne kahramanların kişiliklerini bulması anlamında merkez mekân olarak yer alsa da Uzunköprü, İpsala, Keşan gibi mekânlara da değinilir. Romanda başkahraman Turhan Tuna, imar planını yaparken Edirne'yi gelişmiş bir vatan parçası haline getirmek için her ayrıntıya ayrı önem verir, tasarılarını buna göre yapar. Halk için gerekli her mekân projede en ideal şekliyle çizilir ve Edirne geçmişteki saltanat günlerine yaklaştırılmaya çalışılır. 
Edirne için hazırladığım “Atatürk Sitesi” bitmek üzeredir. Anıt Meydanı, halk jimnastik holleri, açık spor alanları, halk için hamamlar, konser, kitap evleri. Bunları en ince bölümlere kadar işledim. (Erol, 2015b: 5o)

Turhan Tuna'nın imar planlarının ayrıntıları kadar, yapılacak olan imarın hem yazar hem de kahraman açısından önemi romana yansır. Kahramanın zamana zaman aşkın verdiği melankolik durum sonucunda ölüm korkusuna kapıldığı görülür. Aşk ve ölüm sorgulamalarının yapıldığı bölümlerde bile Edirne ve Trakya'nın imar planlarının yarım kalmasından endişe edildiği görülür.

Ölürsem yerineceğim tek bir şey yer vardı: Planlarımı bitirmeden, Trakya’mın imarını görmeden ölmek. Yoksa Canzi uğruna yanıp tükenmek başlı başına bir saadet olacaktı (Erol, 2015:44-45).

David Harvey (2013: 11) mekânı, “ insanı biçimlendiren ve onun tarafından biçimlendirilen toplumsal bir boyut” olarak kabul eder. Bireysel ve toplumsal bütün davranışlar, mekân düzleminde anlam kazanır. Ciğerdelen'de asıl olay örgüsü içinde aktarılan Sarı Sipâhîler, Yedi Peçeli ve Ciğerdelen Efsanesi adlı üç hikâyede bireysel ve toplumsal davranışların anlam kazandığı mekân Şahinkonak’tır. Burası din büyüklerinin ve tarihi kişilerin yurt edindiği yerdir. Türk kültür ve geleneklerinin burada yaşatıldı̆̆ görülür. Bayram hazırlıkları, kutlamalar, evlilik geleneği, hamam kültürü, konak hayatı, bütün ayrıntıları ile resmedilir. Bireysel duygular ve davranışlar, Şahinkonak’ta toplumsal süreçlere dönüşerek millî kimliğin karaktere dönüşümünde mekânın işlevsellik kazanmasına hizmet eder.

\begin{abstract}
Onu bir Türk hamamına soktular, şöyle bir yıkadılar, saçlarını kokulu yağlarla tarayıp ördüler. Ham ipekten çamaşırlar, al atlastan Türk elbiseleri, kürk giydirdiler. Ocaklı bir odada yumuşak minderlerle çevrili bir sini kenarına oturttular, dizlerine işlemeli peşkir örttüler, önüne kapağı kuşlu bir küçük kâse koydular, eline mercan saplı bağa kaşık verdiler (Erol, 2015b: 77).
\end{abstract}

Edirne, yazarın gönlündeki yeri ile yıllarca yaşadı̆̆ı Avrupa ülkelerinden daha üstün bir yerdedir. Yazar, Avrupa ülkelerine göre oldukça küçük ve bakımsız olan Edirne'de adım attıkça toprağın altındaki köklerinin filizlendiğini hisseder. Erol (2015b: 15), Keşan’ı anlatırken “yurdumdur; taşına toprağına fedayım" sözlerini sıkça sarf eder. Edirne ata yurdu olarak anlam kazandığından bazen karşılaştırmalarla bazen de kişisel duygusallıklarla mekânın biricikliği vurgulanır.

Bütün batı ülkelerini adım adım dolaştım, ne zenginlikler, ne mâmûreler gördüm, kasabam onların yanında saray önüne kurulmuş çerge bile değildir. Fakat ben hiçbir yerde ayağımı burada bastığım gibi basamam (Erol, 2015b: 15).

Romanda Edirne'den sonra ikinci mekân olarak İstanbul ele alınır. Turhan Tuna'nın âşı olduğu Canzi, İstanbul'da oturur. Turhan Edirne'de Türk kültürünün temsilciliğini yaparken Canzi İstanbul'da modern ve eğitimli Cumhuriyet kadını kimliği ile yeni yaşamı yansıtır. Canzi’nin İstanbul'da yaşadığı Ayazpaşa'daki apartman dairesi olayın karmaşıklaştı̆̆ı yerdir. Romanın birçok yerinde bu yer, Canzi ile Turhan’ın aşk yuvası olarak tasvir edilir. Ancak bu apartman dairesi daha sonra Canzi için kötü bir tecrübenin yaşandığı yere dönüşür. Turhan'ın kıskançlık krizine girerek Canzi’ye cinsel saldırıda bulunmaya çalışması bu evde yaşanan bütün güzel anılara gölge düşürür.

\title{
4. Ait olamama ve kendini buluş: Dineyri Papazı
}

Dineyri Papazı, 1940’lı yıllarda İstanbul'da yaşayan Gülbün adlı genç bir kızın evli ve kendinden yaşça büyük zengin iş adamı Ayhan Cimşidoğlu'na duyduğu yasak aşkı konu edinir. Yazarın mekân tercihleri, kahramanın psikolojisini yansıtması bakımından önemlidir. Çünkü mekân bireyin hayatını şekillendiren bir unsur olarak anlam kazanır. Romanda mekân, Gülbün'ün yaşadıklarına bağlı olarak değişir. Çünkü o, ailesini kaybettiğinden çeşitli evlerde başkalarının yanında hayata tutunmaya çalışır. 
İlk olarak Bağlarbaşı’ndaki bir ailenin evi, hem sığınak hem de sorunların ortaya çıktığı yer olarak ele alınır. Küçük bir ortaokul öğrencisiyken evin bütün ağır ev işleri kahramana yüklendiğinden bu ev, onun için sorunların başladığı yerdir. Gülbün bu evdeyken okuldaki sorumluluklarıyla ev işlerini bir arada yürütebilmenin ağırlığı altında ezilir. Bağlarbaşı'ndaki bu evden ayrılınca çocuk bakıcısı olarak Luçi adlı İtalyan bir ailenin yanına yerleşir. İstanbul'da görevleri nedeniyle bulunan bu ailenin yaşadıkları evin tasvirlerinde, Mühürdar semti ve kırmızı geniş tuğlalı, güzel bir ev öne çıkarılır. Gülbün, on dört yaşında bir çocukken girdiği bu evde ailenin çocuğu gibi muamele görmüş, yirmi bir yaşında bir genç kız olana kadar bu evde kalarak hayatının en güzel ve mutlu günlerini bu evde geçirir. Lucilerin ülkelerine dönmesiyle genç kızın yaşadığı güzel günler, son bulur. Bachelard (1996: 43), "Doğduğumuz ve büyüdüğümüz ev, başka hiçbir mekânla klyaslanmayacak kadar derinden etkiler insanı” diyerek evin insan için taşıdığı önemi ifade eder. Gülbün'ün doğduğu ev olmasa da çocukluktan gençliğe kadar geçen zaman dilimini geçirdiği Mühürdar'daki ev, huzurlu ve güzel bir yaşamın mekânı olarak kahramanın hayatında önem kazanır. Genç kız yetim ve öksüz kaldıktan sonra Luçilerin yanında geçirdiği saf, tertemiz yaşamını ve bu eve olan özlemini sık sık dile getirir.

O konak yavrusu binada bir arada nasıl kaynaşmış, nasıl kol kola kenetlenmişlerdi! O huzur, o güzellik, o ahenk, kamışın ucundan üfürülünce havaya yükselen, nazlı nazlı salınarak yükselen, sonra birden bire yok olan elvan dünya! (Erol, 2014b: 156).

Luçilerin evinde çalışan Müyesser'in Kurbağalıdere'deki evi Gülbün'ün yaşadığı bir diğer mekândır. Müyesser ve Akif Kaptan, yalnız bırakmak istemediklerinden Luçilerin evinden ayrıldıktan sonra onu yanlarına kabul ederler. Bu bahçeli, küçük ahşap ev, kahramanın kadınlığa adım atışına şahitlik eder. Bu mekânda yaşadıklarından sonra yasak aşkın etkisiyle bir çıkmaza girdiği dönem anlatılır. Feyzi Bey, Doktor Bülent ve Talat Bey, kahramanı düşüşten koruyarak benliğini bulma yolundaki yolculuğunun sorunsuz bir şekilde tamamlanmasına yardım ederler. Bu süreçte uyarılar, telkinler ve nasihatler, kahramanı manevi açıdan yönlendirmeyi amaçlar. Gülbün'ün enerjisini harcayacağı başka alanlar bulunarak ona manevi destek verilir. Şüpheli maceraların, kahramanı farklı mekânlara sürüklemesinden doğan korku, kahramanın etrafındaki kişilerin koruyucu ve gerçeği hatırlatıcı rol üstlenmeleri mecburiyetini doğurur.

Doktor Bülent, Gülbün'ü aşırı bir kendini verişten, sonsuz ummanların encâmı şüpheli mâcerâlarına sürüklenişten korumak ister gibiydi (Erol, 2014b: 15).

İstanbul'un birçok semti âdeta haritada işlenircesine romandaki yerini alsa da Gülbün'ün yaşadığı mekânların dışında, Ayhan'la ilişkisinin başladığı ve ilerlediğii, pişmanlık yaşadığı mekânlar daha çok mercek altına alınır. Kadıköy önceki romanlarda işlendiği kadar yasak aşkın başladı̆̆ı ve sırların çözüldüğü yer olarak Dineyri Papazı'nda da mekân olarak seçilir. Kadıköy vapuru Ayhan'la Gülbün'ün ilk defa karşılaşıp tanıştıkları huzur verici bir yerdir. Vapur, zamanla ferahlatıcı etkisini yitirerek kahramanı boğan, daraltan, kafese konulmuşçasına rahatsız eden bir imaj kazanır. Gülbün, bu vapurda masumiyetini yitirerek Ayhan'ın kirli dünyasından içeri girmiştir. Dolayısıyla ileriki zaman diliminde içinde istemli ya da istemsiz olarak bulunacağı kötü mekânların ilk eşiği Kadıköy vapurudur.

Gülbün'ün Ayhan'la birlikte olma kararının ardından buluştuğu mekân, Mühürdar olsa da onu en kötü günlerine ve bir çımaza sürükleyecek yer, Ayhan'ın Beyoğlu'nda Menekşe Apartmanı'ndaki garsoniyeridir. Gülbün buraya gelerek uzun zaman sürecek olan metreslik hayatını kabul etmiş olur. Ayhan'ın psikolojik baskıları, tacizleri ve tehditleri, bu kapıdan girişle başlamıştır. Garsoniyer, normal bir apartman dairesi olmasına rağmen genç kızın gözünde dar, karanlık, zevksiz bir dekorla düzenlenmiş, içinde her türlü ahlaksızlığın yaşandığı bir yer görünümündedir. Ayhan’ın zevklerini tatmin etmek için kullandığı bu dairede eski yaşantısının kalıntıları olarak bir kırmızı sabahlık ve kırmızı 
kadife terlikler bulunmaktadır. Bu eşyalar, apartmana daha önce gelmiş kadınların kullandığı eşyalar olması nedeniyle Ayhan'ın birlikte olduğu kadına bakışını da ortaya koyan delillerdir. Gülbün her ne kadar bu eşyaları kullanmayarak diğer kadınlar ile aynı olmadığını ortaya koymak istese de Ayhan'ın dünyasında onun yeri Menekşe Apartmanı'ndaki diğer kadınlar kadardır. Gülbün, üç aydan sonra bu ilişkiyi bitirme kararı alıp Ayhan'dan kaçmaya çalışır. Kurtuluş'taki Terzi Güzin'in atölyesi, Cağaloğlu'nda Dr. Bülent'in muayenehanesi, Talat Bağcı'nın İhsaniye'deki yalısı gibi birçok yeri, hem çalışma hem de mesken olarak kullanan Gülbün sonunda ruhunu dinlendirip huzur bulacağı bir yere kavuşur.

Dr. Ercüment'in yardımıyla Danimarkalı Yensenlerin Maçka'daki evine yerleşerek Ercüment'le evlenme kararını alan Gülbün, geçirdiği hastalık nöbetlerinden sonra Guraba Hastanesinde tedavi görür. Romanın sonunda Safiye Erol, kendisi için kutsal olan ata yurduna Gülbün’ü de göndererek huzura ermesini ister. Erol, Edirne'de gezerken hissettiği kutsiyet duygusunun kendi benliğine kavuşup huzura erme konusunda Gülbün'e de yarayacağına inanmaktadır. Selimiye'deki gezintiden sonra Gülbün hatalarından dersler almış, ruhu dinlenmiş, hastalıklarından kurtulmuş olarak artık uyanma, millî benliğin bir gereği olarak ülkesine yararlı olma bilinciyle iyileşme göstermeye başlar. Selimiye'nin tarihî ve dinî etkisi onun benliğine işleyerek hastalıklarını iyileştirmiş, "yirmi seneye yirmi senenin kaldıramayacağı hayal tasvirlerini tıkayan” (Erol, 2014: 273) kız, "yıpranmış ve kocamış" masumluğunu yeniden bulur.

\section{Sonuç}

Sonuç olarak Safiye Erol'un romanlarında aşk peşinde koşan kadınların karşılaştığı koşulların alt üst ettiği yaşamları mekân üzerinden ele alınmıştır. Kadınların aldıkları Batı tarzı eğitim, sosyal veya statüleri onların aşk karşısında yanlış yola düşmelerine engel olamamıştır. Dolayısıyla çevre ilişkileri ve etkisi altında kaldıkları aşk, bireylerin hastalıklı bir ruh hâline bürünmelerinde ve kaçışla sonlanan bir yaşamın başlamasında önemli rol oynamaktadır. Safiye Erol'un romanlarında genellikle eğitimli kadın kahramanların, yasak aşk ilişkileri içinde oldukları görülür. Nuran; evli olan Sermet, Canzi kocasından boşanmadan Turhan Tuna, Gülbün ise Ayhan ile birliktedir. Kadıköy romanında Necdet, evli bir kadın olan Bedriye'ye âşıtır. Bu yasak aşk ilişkilerinin ilerlediği, buluşmaların, ayrılmaların ve ihanetlerin gerçekleştiği mekânlar öncelikle aşk yuvası ve kahramanların mutluluğu sonuna kadar yaşadıkları yalılar, köşkler, apartman daireleri olarak tasvir edilir. Ancak kahramanların kıskançlık, değer görmeme, içinde bulundukları durumun toplum değerleriyle örtüşmemesi nedeniyle duydukları vicdan azabı, onların mekânı sorgulamalarına yol açar. Bu durum geniş mekânların dar mekâna dönüşerek bireylerin kaçma, içine kapanma, isyan etme, yalnız kalma isteklerine kapılmalarına neden olur. Çoğu zaman bir kaçışla başlayan bu süreç, kahramanların ağır psikolojik rahatsızlıklar geçirmelerine neden olarak zayıf karakterlerini ve zaaflarını ortaya çıarır. Ancak bu travmalar kahramanı bir yok oluşa değil; aksine bir varoluşa, yeniden doğuşa yönlendirdiğinden kahramanların yeni yerlere doğru yola çıkarak eski çevreden uzaklaştıkları görülür. Bu yol çoğunlukla tasavvufi bir yol ayrımının kişiyi rahatlatıcı etkisiyle şekillenir. Kaçış isteği ve ruh hâlinin verdiği sıkıntıyla sık sık mekân değiştiren kahramanların derin bir bunalım yaşamaları, yaptıkları yanlışın farkına varışları ve yanlıştan geri dönmek istemelerine rağmen zayıf kişiliklerinin onları alıkoyması mekânın anlam kazanmasına veya yitirmesine neden olmaktadır. Batı değerleri ve modernizmin ortaya çıkardığı yaşam şekilleri üzerine yoğunlaşan tasvirlerde İstanbul ve semtleri yoğun olarak ele alınırken bireylerin öz benliklerine kavuşmaları, millî değerler ve bilinçle karşılaşarak içine düştükleri zor durumdan kurtuluşları Edirne'nin tarih ve din misyonu ile özdeşleşerek önem kazanmaktadır. 


\section{Kaynakça}

Aristoteles (2001). Poetika. (Çev. İsmail Tunalı). İstanbul: Remzi Kitabevi.

Aytaç, G. (2003). Genel Edebiyat Bilimi. İstanbul: Say Yayınları

Bachelard, G. (1996). Mekânın Poetikası. (Çev. Aykut Derman). İstanbul: Kesit Yayınları.

Balık, M. (2016). "Edebiyat ve Mekân Bağlamında Safiye Erol'un Ülker Fırtınası Romanı Üzerine Bir İnceleme”. International Journal of Cultural and Social Studies (IntJCSS). 2 (2), 119-128.

Çetin, M. A. (2017). "Saf Şiirin Peşinde Üç Poetika: Ahmet Haşim, Ahmet Hamdi Tanpınar, Octavıo Paz”. Türk Dili, S. 789, 75-79.

Erol, K. (2011). "Kültür Değişmesi ve Safiye Erol'un "Kadıköyü’nün Romanı" ve "Ülker Fırtınası" Adlı Romanlarında Kuşak Çatışması”. Mustafa Kemal Üniversitesi Sosyal Bilimler Enstitüsü Dergisi. 8 (16), s. 387-406.

Erol, S. (2014a). Ülker Fırtınası. İstanbul: Kubbealtı Neşriyatı.

Erol, S. (2002). Makaleler. İstanbul: Kubbealtı Neşriyatı.

Erol, S. (2015a). Kadıköyü’nün Romanı. İstanbul: Kubbealtı Neşriyatı.

Erol, S. (2015b). Ciğerdelen. İstanbul: Kubbealtı Neşriyatı.

Erol, S. (2014b). Dineyri Papazı. İstanbul: Kubbealtı Neşriyatı.

Harvey, D. (2013). Sosyal Adalet ve Şehir. İstanbul: Metis Yayınları.

İleri, S.(2015). Edebiyatımızda Sevdiğim Romanlar Kılavuzu. İstanbul: Everest Yayınları.

Okay, O. (1998). Sanat ve Edebiyat Yazıları. İstanbul: Dergâh Yayınları

Roland, B. (1999). Göstergebilimsel Serüven. (Çev. Mehmet Rifat, Sema Rifat). İstanbul: Kaf Yayıncılık.

Özgül, M. K. (2001), “Şiir, Şair ve Sair”, Hece Dergisi, S. 53-55,s. 253.

Sazyek, H. (2000). "Yeni Türk Edebiyatında Manzum Poetik Metinler”. Türk Dili Dergisi, S. 577, s.1022.

Sürmeli Savcan, Y. (2005). Safiye Erol'un Romanları Üzerine Bir İnceleme. Yüksek Lisans Tezi. Osmangazi Üniversitesi Sosyal Bilimler Enstitüsü. Eskişehir.

Todorov, T. (2014). Poetikaya Giriş. (Çev.Kaya Şahin).İstanbul: Metis Yayınları.

Üstün Dumantepe, S. (2004). Safiye Erol'un Eserlerinde Zaman, Mekan, İnsan. Yüksek Lisans Tezi. Celal Bayar Üniversitesi Sosyal Bilimler Enstitüsü, Manisa. 